\title{
How Does the Cortactin Gene Expression Affect Breast Cancer among Iranian Females?
}

\section{Tutunchi Sara1, Saffari Mojtaba², Mazaheri Mahta1, Nourmohammadi Parisa1, Nourmohammadi Bahareh ${ }^{3}$, Shirkoohi Reza ${ }^{2 *}$, Ghasemi Nasrin ${ }^{*}$}

${ }^{1}$ Department of Medical Genetics, Shahid Sadoughi University of Medical Sciences, Yazd, Iran

${ }^{2}$ Group of Genetics, Cancer Research Center, Cancer Institute of Iran, Tehran University of Medical Sciences, Tehran, Iran

${ }^{3}$ Department of Biology, Science and Research Branch, Islamic Azad University, Tehran, Iran

${ }^{4}$ Recurrent Abortion Research Centre, Reproductive Sciences Institute, Shahid Sadoughi University of Medical Sciences, Yazd, Iran

Email: ^rshirkoohi@tums.ac.ir,nghasemi479@gmail.com

How to cite this paper: Sara, T., Mojtaba, S., Mahta, M., Parisa, N., Bahareh, N., Reza, S. and Nasrin, G. (2016) How Does the Cortactin Gene Expression Affect Breast Cancer among Iranian Females? Advances in Breast Cancer Research, 5, 142-149.

http://dx.doi.org/10.4236/abcr.2016.54017

Received: July 19, 2016

Accepted: September 9, 2016

Published: September 12, 2016

Copyright $\odot 2016$ by authors and Scientific Research Publishing Inc. This work is licensed under the Creative Commons Attribution International License (CC BY 4.0).

http://creativecommons.org/licenses/by/4.0/

\section{(c) (i) Open Access}

\begin{abstract}
Introduction: Breast cancer is the most common cancer in the Iranian female population, and the incidence of the disease is rising. Early detection in association with staging or grading the tumor is the most effective method to increase survival rates. Studies have revealed that cortactin overexpression may play a role in the final stages of tumor progression and affects invasion and cellular motility. The aim of this study is to evaluate cortactin gene expression among Iranian female patients with breast cancer. Materials and Methods: Samples belonging to 70 breast cancer patients were randomly selected from the Imam Khomeini tumor bank. Normal and tumor tissues were prepared and stored at $-80^{\circ} \mathrm{C}$. Cortactin gene expression was evaluated by real-time PCR. Finally the data, along with demographic and clinical parameters, were analyzed using Prism 5.0 software, followed by t-test and ANOVA analysis. Results: Cortactin gene expression among tumor tissues increased $95.71 \%$ in comparison with normal tissues. A significant correlation between cortactin gene expression and lymph nodes' involvement $(\mathrm{P}=0.0077)$ and tumor stage $(\mathrm{P}=0.0030)$ was observed. However, tumor grade $(\mathrm{P}=0.8598)$, tumor size $(\mathrm{P}=0.3058)$, and patient's age $(\mathrm{P}=0.4135)$ had no significant correlation with the gene's expression level. Discussion: This study demonstrated that the cortactin gene's overexpression in breast cancer may enhance lymph nodes' involvement. This study also found that the gene's expression was raised significantly in progressed stages of the cancer. Therefore, cortactin gene overexpression is an important factor indicating breast cells' invasion. Conclusion: The cortactin gene's expression level can be considered an accurate indicator for female breast cancer and also an appropriate biomarker for this cancer in clinical evaluations.
\end{abstract}




\section{Keywords}

Breast Cancer, Iranian Female, Cortactin Gene Expression, Lymph Nodes'

\section{Introduction}

At the beginning of the 20th century, with the brilliant medical developments that led to control of infectious disease, few could imagine that non-communicable diseases (NCDs) would offer the strongest clinical challenge in the next century. It is estimated that 38 million people die due to NCDs annually, and nearly three quarters of them (28 million) live in less-developed countries [1]. Cancer, a major public health problem worldwide, is currently the second-leading cause of death, causing over 8 million deaths a year, second only to cardiovascular diseases, and cancer is expected to surpass cardiovascular diseases as a cause of death within the next few years [2]. Due to population growth and the aging of the population, cancer rates are increasing. In addition, the general risk factors for NCDs, such as smoking, overweight, physical inactivity, and changing reproductive patterns in association with urbanization and economic development are raising cancer rates [3]. Lung cancer is the leading cause of cancer death among both sexes in developed countries, while breast cancer remains the most prevalent cause of death among females in less-developed countries [4]. In countries with powerful economies, thanks to developments in early detection methods and improved treatments, cancer incidence and mortality rates are decreasing [5]. However, the data demonstrate that in many countries of South America, Africa, and Asia cancer rates have been increasing, most likely due to lifestyle changes [6] [7]. Breast cancer is among the five most common cancers in Iranian women. Although Iranian women are familiar with the disease [8], the incidence of breast cancer is rising; most Iranian females suffer from later developed stages (III or IV), and they are also relatively younger (about 10 years) than their Western counterparts [9] [10].

Breast cancer is a heterogeneous association of tumors that have different clinical, pathologic, and radiographic indications [11]. Ductal and lobular carcinomas are the two most common histologic types of invasive breast cancer [12]. In addition, breast cancer can be classified via different commonly-used methods, including staging the tumor through the TNM system [13] [14], and grading the tumor through the Nottingham grading system, or the Scarf-Bloom-Richardson system [15] [16]. To reduce mortality rates and improve the patients' prognosis, early detection in association with staging or grading the tumor is used [17].

The cortactin gene $(C T T N)$ is located on the amplicon 11q13, which is often reported to be overexpressed in human cancers, such as breast and bladder cancers, and esophagus, epithelium, and hepatocellular carcinomas [18] [19]. Recent studies indicated that cellular motility increased, and no cell-to-cell cohesion was necessary for tumor progression. Cortactin is among the most important actin-assembling proteins [20]. Cortactin's ability to interact with cytoskeleton proteins via the SH3 domain 
makes it correlate with a variety of processes, such as endocytosis and cell migration. This protein is also responsible for invadopodia formation. Cancer cells decompose the extra-cellular matrix through the invadopodia used for cell migration [21]. Cortactin phosphorylation, acetylation, and deacetylation have been demonstrated, which are assumed to be important for cancer progression [22]. Although cortactin's action within tumor progression is not clearly understood, it seems that high expression of CTTN correlates with patients' worse prognosis or disease relapse. This means that CTTN overexpression may play a role in the final stages of tumor progression. Studies also reveal that $C T T N$ overexpression does not lead to morphological changes, and it does not affect proliferation but instead influences invasion and cellular motility [18] [23].

In this study, we evaluated cortactin gene expression among Iranian female patients with breast cancer to determine the correlation between cortactin gene expression with tumor size, grade and stage and also patients' age.

\section{Material and Methods}

Population study and tissue specimens: Seventy female patients suffering from breast cancer, who were under the treatment at the Imam Khomeini hospital from 2013-2014, were evaluated. Informed consent was obtained from each patient. Samples were obtained from the Imam Khomeini hospital's tumor bank. Each sample then was stored at $-80^{\circ} \mathrm{C}$ until testing was performed.

$R N A$ isolation and $c D N A$ synthesis. RNA extraction was performed using the TriPure Isolation Reagent Kit according to the manufacturer's instructions (Roche, Germany). RNA quantity analysis was approached spectrophotometrically. cDNA was synthesized using the PrimeScript RT Reagent Kit (Roshe, Mannheim, Germany) according to the manufacturer's instructions.

Sequences of CTTN and GAPDH mRNAs were obtained from the NCBI database, and the desired primers were designed utilizing Primer 3 software (Table 1). Real-time PCR was evaluated using a Rotor Gene 6000 (Corbett Research, Australia) apparatus.

Statistical analysis: For each sample two reactions were applied and final output was calculated as the mean of two repeats. For final statistical analysis Prism 5.0 software was used. According to the obtained TCs from real-time PCR, genes' relationships were assessed via the $2^{\wedge}-\Delta \mathrm{Ct}$ formula with clinical parameters among patients with breast cancer. Statistical significance of each parameter was analyzed by ANOVA $(\mathrm{P} \leq 0.05)$ and t-test.

Table 1. Primer sequences for CTTN and GAPDH target genes.

\begin{tabular}{cc}
\hline Primer Name & Sequence $\left(5^{\prime} \rightarrow \mathbf{3}^{\prime}\right)$ \\
\hline$C T T N$ Forward & CACAAGCTGAGGGAGAATGT \\
$C T T N$ Reverse & CGAGCAGTGCTTGGAAAGTT \\
GAPDH Forward & GAAGGTGAAGGTCGGAGTCA \\
$G A P D H$ Reverse & AATGAAGGGGTCATTGATGG \\
\hline
\end{tabular}




\section{Results}

Pathological information: Samples were provided from the Imam Khomeini hospital tumor bank, including 70 tumor samples and 5 normal tissue samples that were utilized as controls. Patients' clinical and pathologic characteristics were recorded (Table 2).

CTTN gene expression: level of CTTN gene expression among normal and tumor tissues: CTTN gene expression among tumor tissues was increased $95.71 \%$ in comparison with normal tissues (Figure 1).

The correlation between the level of $C T T N$ gene expression and lymph node involvement, tumor grade, tumor stage, tumor size, and patient's age were evaluated.

Table 2. Clinical characteristics of 70 patients with breast cancer.

\begin{tabular}{ccc}
\hline Variable & Number & \\
\hline \multirow{2}{*}{ Lymph node status } & No & 32 \\
& N & 38 \\
TNM staging & I & 3 \\
& II & 38 \\
Histological grading & III & 29 \\
& 1 & 9 \\
Tumor size & 2 & 37 \\
& 3 & 24 \\
Age & T1 & 5 \\
& T2 & 47 \\
T3 & 18 \\
& $<50$ years & 37 \\
\hline
\end{tabular}

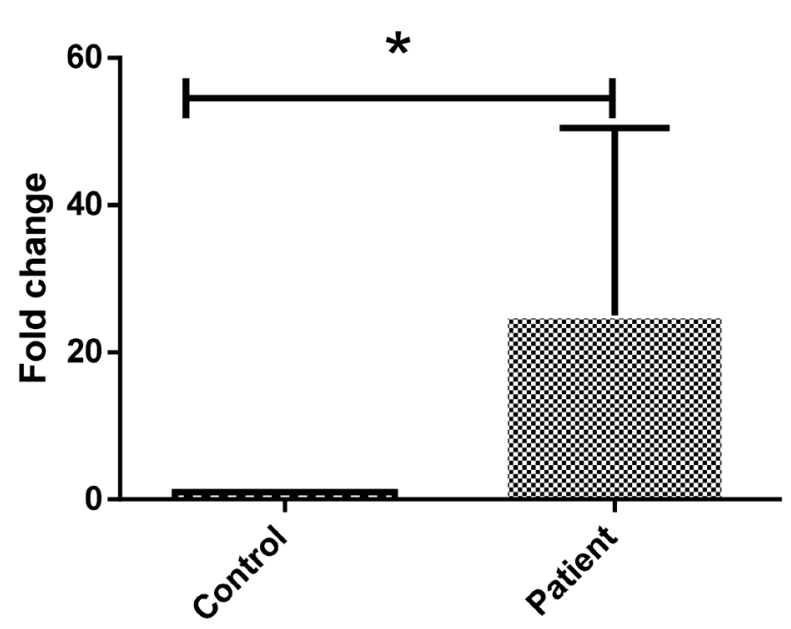

Figure 1. CTTN gene expression levels: Thirty patients (47.14\%) had a low level of $C T T N$ expression (+), while 20 patients (28.67\%) displayed a moderate CTTN expression (++), and there was a high expression (+++) of the gene in 17 patients $(24.29 \%)$. The comparison between these different groups was performed by $\mathrm{t}$-test and ANOVA. ${ }^{*}$ mean $\mathrm{P}$ value $<0.0001$. 
A significant correlation between $C T T N$ gene expression and lymph nodes' involvement and tumor stage were observed. According to the results, the CTTN expression level was higher among patients who had lymph nodes' involvement (Figure 2(a)). Patients with cancer are classified based on their tumor stage: I, II, III, and IV. Due to

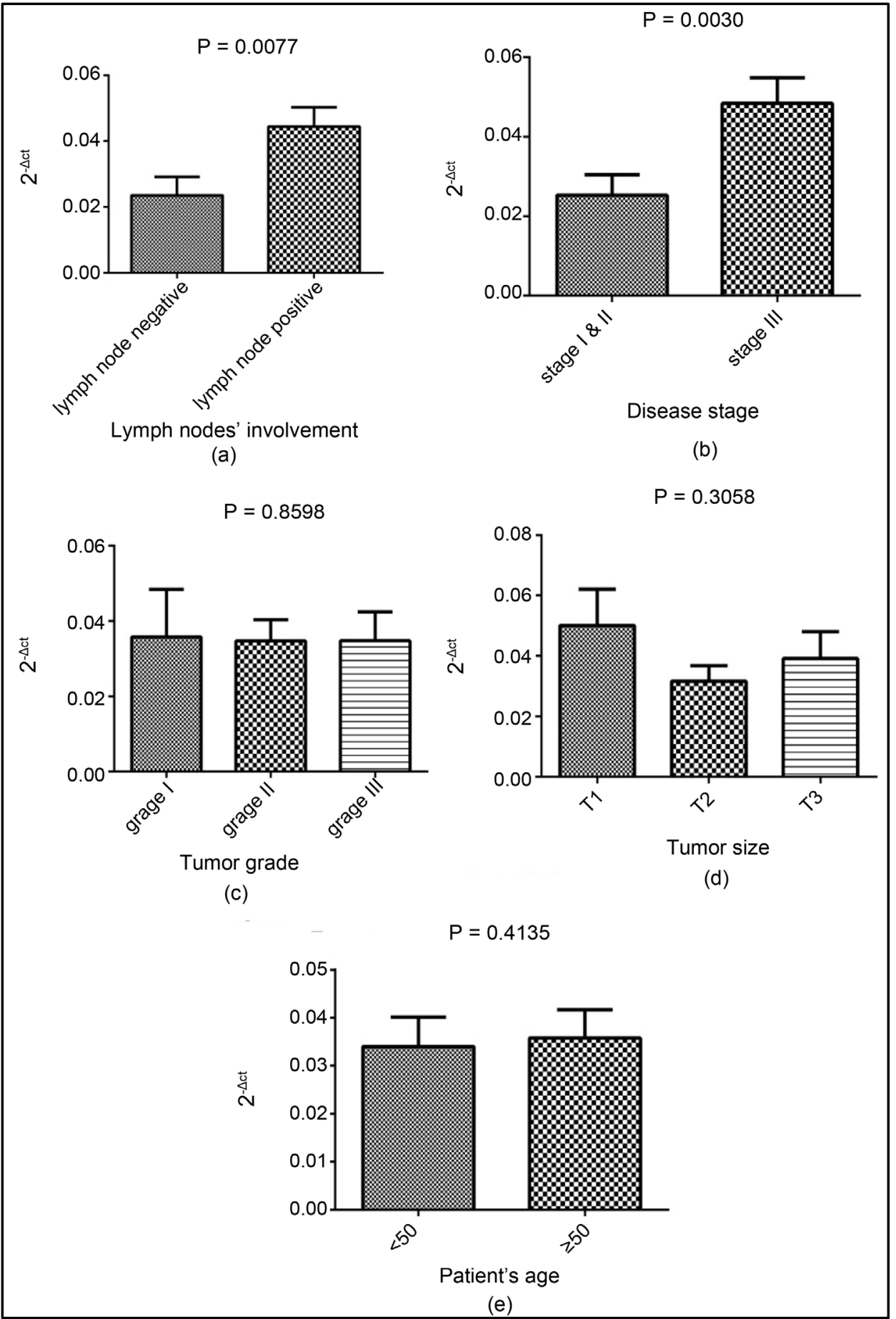

Figure 2. The correlation between the level of CTTN gene expression and lymph node involvement (a), tumor grade (b), tumor stage (c), tumor size (d), and patient's age (e). 
metastasis to other organs or areas of the body, such as the liver, brain, and bones, stage IV patients were excluded. In addition, due to the small size of the sample groups, stage I and stage II patients were merged into one group, and patients at stage III were considered a separate group. Based on results between CTTN gene expression and disease stage, a significant correlation was observed (Figure 2(b)). However, tumor grade (Figure 2(c)), tumor size (Figure 2(d)), and patient's age (Figure 2(e)) revealed no significant correlation.

\section{Discussion}

This study's results revealed that the cortactin gene's expression was increased in 95.71\% of tumor samples. Cortactin is an action-binding protein. Its overexpression prevents cell junctions, facilitating tumor's spread [24]. Despite indications of cortactin's overexpression effects on carcinoma cell migration, invasion, and metastasis, its exact mechanism of action in cancer progression is not yet completely understood [25]. In this study, evaluating cortactin gene expression and lymph nodes' involvement demonstrated that this gene's overexpression in breast cancer may enhance lymph nodes' involvement. In addition, the gene's expression was raised significantly at more progressed stages of cancer. In agreement with this study's results, Tsai et al. investigated the correlation of cortactin expression with gastric adenocarcinoma clinical parameters through immunohistochemical and tissue microarray analysis [26]. They determined that cortactin overexpression had a direct relationship with more progressed stages of that cancer.

In addition, Sang Jae et al. reported cortactin overexpression among 58\% of nonsmall cell lung cancer patients [27] and cortactin overexpression was remarkably associated with other clinical factors, including tumor size, and lymph nodes' involvement. Chen et al's 2011 survey of breast cancer patients, using immunohistochemistry and tissue microarray, revealed that $23.2 \%$ of the patients had low CTTN expression (+), $60.6 \%$ had moderate $C T T N$ expression (++), and $16.2 \%$ indicated high levels of $C T T N$ expression $(+++)$. However, Chen et al. did not report a significant correlation between cortactin expression and age, tumor grade, lymph nodes' circumstances, or tumor stage, which could result from the cancer's heterogeneity [20].

In other studies that evaluated cortactin gene expression among a variety of cancers, the gene's overexpression was in direct correlation with cancer cell invasion and proliferation capability. Subsequently, based on this study's results, it could be claimed that cortactin gene overexpression is an important factor in breast cells' invasion. However, no significant correlation was observed between the studied gene's expression and tumor grade or size. The small sample size used in this study may be the cause for this result. Higher expression of the gene among the patients belonging to the elder age group, however this result was not statistically significant.

\section{Conclusion}

According to the results of this study, the cortactin gene expression level can be consi- 
dered an indicator for female breast cancer and also an appropriate biomarker for this cancer in clinical evaluations. Subsequently, molecular inhibitors, including micro RNAs, can be designed to prevent the protein production by this gene and to restrict its action, and therefore the progression of breast tumors. Despite the valuable information garnered from this study, which improved our understanding of invasive behavior, metastasis mechanisms, and control methods for breast carcinoma cells, more studies are needed to carry these findings further.

\section{References}

[1] Mendis, S., Davis, S. and Norrving, B. (2015) Organizational Update The World Health Organization Global Status Report on Noncommunicable Diseases 2014; One More Landmark Step in the Combat Against Stroke and Vascular Disease. Stroke, 46, e121-e122. http://dx.doi.org/10.1161/STROKEAHA.115.008097

[2] Torre, L.A., Bray, F., Siegel, R.L., Ferlay, J., Lortet-Tieulent, J. and Jemal, A. (2015) Global Cancer Statistics, 2012. CA: A Cancer Journal for Clinicians, 65, 87-108. http://dx.doi.org/10.3322/caac.21262

[3] Riley, L., Guthold, R., Cowan, M., Savin, S., Bhatti, L., Armstrong, T., et al. (2016) The World Health Organization STEPwise Approach to Noncommunicable Disease Risk-Factor Surveillance: Methods, Challenges, and Opportunities. American Journal of Public Health, 106, 74-78. http://dx.doi.org/10.2105/AJPH.2015.302962

[4] Siegel, R.L., Miller, K.D. and Jemal, A. (2016) Cancer Statistics, 2016. CA: A Cancer Journal for Clinicians, 66, 7-30. http://dx.doi.org/10.3322/caac.21332

[5] Lam, W., Chan, C., Chan, C., Mak, C., Chong, K., Leung, M., et al. (2008) Factors Affecting the Palpability of Breast Lesion by Self-Examination. Singapore Medical Journal, 49, 228.

[6] Anderson, B.O. and Jakesz, R. (2008) Breast Cancer Issues in Developing Countries: An Overview of the Breast Health Global Initiative. World Journal of Surgery, 32, 2578-2585. http://dx.doi.org/10.1007/s00268-007-9454-Z

[7] Rizwan, M. and Saadullah, M. (2009) Lack of Awareness about Breast Cancer and Its Screening in Developing Countries. Indian Journal of Cancer, 46, 252. http://dx.doi.org/10.4103/0019-509X.52969

[8] Montazeri, A., Vahdaninia, M., Harirchi, I., Harirchi, A.M., Sajadian, A., Khaleghi, F., et al. (2008) Breast Cancer in Iran: Need for Greater Women Awareness of Warning Signs and Effective Screening Methods. Asia Pacific Family Medicine, 7, 1. http://dx.doi.org/10.1186/1447-056X-7-6

[9] Harirchi, I., Ebrahimi, M., Zamani, N., Jarvandi, S. and Montazeri, A. (2000) Breast Cancer in Iran: A Review of 903 Case Records. Public Health, 114, 143-145. http://dx.doi.org/10.1016/s0033-3506(00)00324-3

[10] Mousavi, S.M., Montazeri, A., Mohagheghi, M.A., Jarrahi, A.M., Harirchi, I., Najafi, M., et al. (2007) Breast Cancer in Iran: An Epidemiological Review. The Breast Journal, 13, 383391. http://dx.doi.org/10.1111/j.1524-4741.2007.00446.x

[11] Gøtzsche, P.C. and Jørgensen, K.J. (2013) Screening for Breast Cancer with Mammography. John Wiley \& Sons, Hoboken. http://dx.doi.org/10.1002/14651858.cd001877.pub5

[12] Li, C., Uribe, D. and Daling, J. (2005) Clinical Characteristics of Different Histologic Types of Breast Cancer. British Journal of Cancer, 93, 1046-1052. http://dx.doi.org/10.1038/sj.bjc.6602787

[13] Singletary, S.E. and Connolly, J.L. (2006) Breast Cancer Staging: Working with the Sixth 
Edition of the AJCC Cancer Staging Manual. CA: A Cancer Journal for Clinicians, 56, 3747.

[14] Tanase, K., Thies, E.D., Mäder, U., Reiners, C. and Verburg, F.A. (2016) The TNM System (Version 7) Is the Most Accurate Staging System for the Prediction of Loss of Life Expectancy in Differentiated Thyroid Cancer. Clinical Endocrinology, 84, 284-291. http://dx.doi.org/10.1111/cen.12765

[15] Wang, M., Klevebring, D., Lindberg, J., Czene, K., Grönberg, H. and Rantalainen, M. (2016) Determining Breast Cancer Histological Grade from RNA-Sequencing Data. Breast Cancer Research, 18, 1. http://dx.doi.org/10.1186/s13058-016-0710-8

[16] Islam, M.S., Kabir, E., Jeba, R., Islam, M.N., Khan, H.R. and Begum, S. (2015) Grading of Breast Cancer-A Short Review. Sir Salimullah Medical College Journal, 15, 95-99.

[17] Calonge, N., Petitti, D.B., DeWitt, T.G., Dietrich, A.J., Gregory, K.D., Grossman, D., et al. (2009) Screening for Breast Cancer. Annals of Internal Medicine, 151, 716-726. http://dx.doi.org/10.7326/0003-4819-151-10-200911170-00008

[18] Li, Y., Tondravi, M., Liu, J., Smith, E., Haudenschild, C.C., Kaczmarek, M., et al. (2001) Cortactin Potentiates Bone Metastasis of Breast Cancer Cells. Cancer Research, 61, 69066911.

[19] Dedes, K.J., Lopez-Garcia, M.-A., Geyer, F.C., Lambros, M.B., Savage, K., Vatcheva, R., et al. (2010) Cortactin Gene Amplification and Expression in Breast Cancer: A Chromogenic in Situ Hybridisation and Immunohistochemical Study. Breast Cancer Research and Treatment, 124, 653-666. http://dx.doi.org/10.1007/s10549-010-0816-0

[20] Sheen-Chen, S.-M., Huang, C.-Y., Liu, Y.-Y., Huang, C.-C. and Tang, R.-P. (2011) Cortactin in Breast Cancer: Analysis with Tissue Microarray. Anticancer Research, 31, 293-297.

[21] MacGrath, S.M. and Koleske, A.J. (2012) Cortactin in Cell Migration and Cancer at a Glance. Journal of Cell Science, 125, 1621-1626. http://dx.doi.org/10.1242/jcs.093781

[22] Daly, R. (2004) Cortactin Signalling and Dynamic Actin Networks. Biochemical Journal, 382, 13-25. http://dx.doi.org/10.1042/BJ20040737

[23] Zhao, G., Huang, Z.-M., Kong, Y.-L., Wen, D.-Q., Li, Y., Ren, L., et al. (2013) Cortactin Is a Sensitive Biomarker Relative to the Poor Prognosis of Human Hepatocellular Carcinoma. World Journal of Surgical Oncology, 11, 74. http://dx.doi.org/10.1186/1477-7819-11-74

[24] Ormandy, C.J., Musgrove, E.A., Hui, R., Daly, R.J. and Sutherland, R.L. (2003) Cyclin D1, EMS1 and 11q13 Amplification in Breast Cancer. Breast Cancer Research and Treatment, 78, 323-335. http://dx.doi.org/10.1023/A:1023033708204

[25] Hirakawa, H., Shibata, K. and Nakayama, T. (2009) Localization of Cortactin Is Associated with Colorectal Cancer Development. International Journal of Oncology, 35, 1271-1276. http://dx.doi.org/10.3892/ijo_00000444

[26] Tsai, W.-C., Jin, J.-S., Chang, W.-K., Chan, D.-C., Yeh, M.-K., Cherng, S.-C., et al. (2007) Association of Cortactin and Fascin-1 Expression in Gastric Adenocarcinoma: Correlation with Clinicopathological Parameters. Journal of Histochemistry \& Cytochemistry, 55, 955 962. http://dx.doi.org/10.1369/jhc.7A7235.2007

[27] Noh, S.J., Baek, H.A., Park, H.S., Jang, K.Y., Moon, W.S., Kang, M.J., et al. (2013) Expression of SIRT1 and Cortactin Is Associated with Progression of Non-Small Cell Lung Cancer. Pathology-Research and Practice, 209, 365-370.

http://dx.doi.org/10.1016/j.prp.2013.03.011 
Submit or recommend next manuscript to SCIRP and we will provide best service for you:

Accepting pre-submission inquiries through Email, Facebook, LinkedIn, Twitter, etc. A wide selection of journals (inclusive of 9 subjects, more than 200 journals)

Providing 24-hour high-quality service

User-friendly online submission system

Fair and swift peer-review system

Efficient typesetting and proofreading procedure

Display of the result of downloads and visits, as well as the number of cited articles

Maximum dissemination of your research work

Submit your manuscript at: http://papersubmission.scirp.org/ 